\title{
Allelopathic effect of aqueous extract of Cyperus rotundus on Lactuca sativa and Solanum lycopersicum
}

\section{Efeito alelopático do extrato aquoso de Cyperus rotundus em plantas de Lactuca sativa e Solanum lycopersicum}

\author{
Eduardo Fernando BISPO'; Natália Barreto MENESES²; Geslanny Oliveira SOUSA; \\ Francisco de Assys Romero da Mota SOUSA ${ }^{3}$; Eleonora Barbosa Santiago da COSTA
} 1 Instituto Taquaritinguense de Ensino Superior Dr. Aristides de Carvalho Schlobach (ITES), Praça Doutor Horácio
Ramalho, 159, Taquaritinga, SP, 15900-000. agroduu@gmail.com
2 Universidade Estadual da Região Tocantina do Maranhão, Rua Godofredo Viana,, 1300, Centro, Imperatriz, MA,
$65900-000$. nbmeneses@yahoo.com.br. Geslannyoliveira1@gmail.com.
3 Programa de Pós Graduação em Agronomia, Universidade Federal da Paraíba, Centro de Ciencias Agrárias Campus
II, Areia, PB, 58397-000. assis.agronomia@gmail.com; eleonorasantiago@hotmail.com.

Recebido em: 20-06-2019; Aceito em: 23-10-2019

\begin{abstract}
The demand for vegetables was reinforced by the search for healthier foods, favoring increased sales of fresh products. Lettuce (Lactuca sativa L.) and tomato (Solanum lycopersicum L.) are the most cultivated vegetables in Brazil, thus being economically important. This study evaluates the allelopathic effect of aqueous extract of nutgrass (Cyperus rotundus) on lettuce (Lactuca sativa) and tomato (Solanum lycopersicum) plants, aiming to analyze its influence on species development. Two trials were conducted in the premises of the Taquaritinguense Institute of Higher Education (ITES) in Taquaritinga city, São Paulo State, under temperatures ranging from $14{ }^{\circ} \mathrm{C}$ to $28{ }^{\circ} \mathrm{C}$, in a greenhouse. The variables analyzed were: fresh shoot and root weight $(\mathrm{g})$, using a semianalytical scale; and root length $(\mathrm{cm})$, using a ruler. Cyperus rotundus leaf extract at higher concentrations positively affected the early growth of vegetables. Studies on allelopathic effects between plants are extremely important because the use of this extract can contribute to seedling growth. The $200 \%$ concentration of Cyperus rotundus extract increased root and shoot development in tomato crop.
\end{abstract}

Additional keywords: growth; nutgrass; production; vegetables.

\begin{abstract}
Resumo
A demanda por hortaliças foi reforçada pela busca de alimentos mais saudáveis, favorecendo também o crescimento da venda do produto fresco. A alface (Lactuca sativa L.) e o tomate (Solanum lycopersicum L.) são as hortaliças mais cultivadas no Brasil, que apresentam importância econômica. O objetivo do trabalho foi avaliar o efeito alelopático do extrato aquoso de tiririca (Cyperus rotundus) em plantas de alface (Lactuca sativa) e tomate (Solanum lycopersicum), visando avaliar a influência no desenvolvimento das espécies. Dois ensaios foram conduzidos, ambos nas dependências do Instituto Taquaritinguense de Ensino Superior (ITES) localizado no município de Taquaritinga, estado de São Paulo, sob temperaturas variando de $14{ }^{\circ} \mathrm{C}$ a $28{ }^{\circ} \mathrm{C}$, em casa de vegetação. As variáveis analisadas foram: Massa fresca da parte aérea e das raízes das plantas ( $\mathrm{g}$ ), utilizando balança semianalítica e comprimento $(\mathrm{cm})$ da raiz utilizando régua. $\mathrm{O}$ extrato da folha de Cyperus rotundus nas concentrações mais elevadas provocaram efeitos benéficos no crescimento inicial das hortaliças. Estudos sobre efeito alelopático entre plantas são de extrema importância, uma vez que a utilização desse extrato pode contribuir com o crescimento das mudas. A concentração de $200 \%$ do extrato de Cyperus rotundus, aumentou o desenvolvimento da raiz e parte aérea na cultura do tomateiro.
\end{abstract}

Palavras-chave adicionais: crescimento; hortaliças; produção; tiririca.

\section{Introduction}

Lettuce (Lactuca sativa L.) and tomato (Solanum lycopersicum) are the most cultivated vegetables in Brazil, thus being socioeconomically important. These crops provide employment, income, and currency for the country, playing a significant social role. The demand for these vegetables has been reinforced by the search for healthier foods, favoring increased sales of fresh products (Carvalho \& Pagliuca, 2007; Silva et al., 2017).

One of the stages that most influence vegetable production is seedling formation, directly affecting the performance and yield of the crop to be planted (Costa et al., 2011). In this sense, composting and vermicomposting are organic matter recycling tools that stand out in plant growth. These techniques aim to reduce contaminants found in residues, which are 
converted into biofertilizers, enabling nutrient recycling in the soil (Domínguez et al., 2010).

The effect characterized as allelopathy corresponds to the interference of substances produced in the secondary metabolism of plants. When released into the environment, these substances may influence the development of other plant species (Carvalho et al., 2011; Monquero et al., 2009). Weed management is a current necessity because weeds are widely distributed in agricultural systems and there is a yield loss of $9.7 \%$ as a result of 1,800 different types of weeds in agricultural crops per year. Management to reduce these weed species can be performed in different ways (Li \& Wang, 2010; Shah et al., 2016; Shah et al., 2017).

However, to obtain the allelopathic substances of a given plant material, it is important to observe ideal temperatures and specific solvents, which will allow the most efficient and complete extraction of substances with greater allelopathic effect (Leão et al., 2016).

According to the literature, treatment with high concentrations of aqueous extract of Cyperus rotundus leaves decreased the germination percentage of turnip, broccoli, cauliflower, and radish seeds. The authors also observed a reduction in the germination percent- age of lettuce and tomato seeds, regardless of the extract concentration used, and a reduction in cabbage germination percentage, at 90 and $100 \%$ extract concentrations (Andrade et al., 2009).

Several studies demonstrate that Cyperus rotundus extract can regulate some substances in plant metabolism, influencing the rooting of some species in a manner similar to auxins (Souza et al., 2012).

This study evaluates the allelopathic effect of aqueous extract of nutgrass (Cyperus rotundus) on lettuce (Lactuca sativa) and tomato (Solanum lycopersicum) plants, aiming to analyze its influence on plant development.

\section{Materials and methods}

Two trials were conducted with lettuce (Lactuca sativa) and tomato (Solanum lycopersicum) crops in the premises of the Taquaritinguense Institute of Higher Education (ITES) in Taquaritinga city, São Paulo State, under controlled temperatures ranging from $14{ }^{\circ} \mathrm{C}$ to $28^{\circ} \mathrm{C}$, in a greenhouse.

Doses were proposed according to Villa et al. (2016), using $1 \mathrm{~g}$ of Cyperus rotundus leaves in $10 \mathrm{~mL}$ distilled water (Table 1).

Table 1- Treatments evaluated in the experiment.

\begin{tabular}{|c|c|c|}
\hline Treatment & Lettuce & Tomato \\
\hline $\mathrm{T} 1-0 \%$ & $0{\mathrm{~g} 10 \mathrm{~mL}^{-1}}^{-1}$ & $0{\mathrm{~g} 10 \mathrm{~mL}^{-1}}^{-1}$ \\
\hline T2 - 50\% & $0.5 \mathrm{~g}_{10 \mathrm{~mL}^{-1}}$ & $0.5 \mathrm{~g} 10 \mathrm{~mL}^{-1}$ \\
\hline T3-100\% & $1{\mathrm{~g} 10 \mathrm{~mL}^{-1}}^{-1}$ & $1 \mathrm{~g} 10 \mathrm{~mL}^{-1}$ \\
\hline T4 - 150\% & $1.5 \mathrm{~g} 10 \mathrm{~mL}^{-1}$ & $1.5 \mathrm{~g} 10 \mathrm{~mL}^{-1}$ \\
\hline T5 - 200\% & $2 \mathrm{~g} 10 \mathrm{~mL}^{-1}$ & $2 \mathrm{~g} 10 \mathrm{~mL}^{-1}$ \\
\hline
\end{tabular}

The experimental design was completely randomized (CRD), consisting of five treatments (nutgrass extract concentrations) with five replicates, totaling 25 experimental units. Each experimental unit consisted of a pot containing one plant.

In the preparation of aqueous extract of Cyperus rotundus leaves, the material was randomly collected from the plants. Cyperus rotundus leaves were previously washed with running water and crushed in a processor, the material was then filtered and applied to lettuce and tomato crops.

Lettuce plants used in the experiment were curly and purple, with a cycle ranging from 35 to 40 days after transplanting. The tomato variety used was Rio Grande, which is a variety for industrial processing. It has undetermined growth and a cycle of 110 to 120 days after transplanting.

Twenty five 5 -liter pots with $60 \%$ soil and $40 \%$ Carolina ${ }^{\circledR}$ commercial substrate were used in the initial growth tests of each species.

Seedlings were transplanted at 25 days after sowing in tomato crop and 20 days after sowing in lettuce crop.

Experiments were carried out for 47 days after seedling transplantation (DAT) in lettuce crop and for 37 days DAT in tomato crop. Extracts were applied weekly via foliar spray.
The variables analyzed were: fresh shoot and root weight $(\mathrm{g})$, using a semianalytical scale; and root length $(\mathrm{cm})$, using a ruler.

The obtained data were submitted to analysis of variance by the $\mathrm{F}$ test. Moreover, a polynomial regression study was performed, adopting the significant equation with the highest coefficient of determination. The AgroEstat Statistical Software was used in all analyses (Barbosa \& Maldonado Júnior, 2010).

\section{Results and discussion}

The concentrations of aqueous extract of Cyperus rotundus showed no significant difference for shoot fresh weight (SFW) of lettuce, with an overall average value of $104 \mathrm{~g}$ (Table 2). Substances produced by the secondary metabolism of plant species also have chemical characteristics that contribute to their identification. Solubility, for example, is related to the polarity of chemical bonds, i.e., nonpolar compounds are generally soluble in nonpolar solvents, while high polarity compounds are soluble in polar solvents, which agrees with the principle that 'the like dissolves the like' (Martins et al., 2013). Pouteria ramiflora ethanolic extract can reduce primary root and shoot length more significantly than aqueous extract, 
suggesting that allelopathic substances are extracted more effectively when using organic solvent (Oliveira et al., 2014).

There was a significant difference regarding the doses of aqueous extract of Cyperus rotundus on lettuce root fresh weight (RFW) and root length (RL) (Table 2). The maximum concentration of the extract $(200 \%)$ provided higher performance in the analyzed variables for lettuce, with $131.4 \mathrm{~g}$ shoot fresh weight, $25.76 \mathrm{~g}$ root fresh weight, and $26.4 \mathrm{~cm}$ root length.

Table 2 - Variance analysis for shoot fresh weight (SFW), root fresh weight (RFW), root length (RL) of lettuce as a function of Cyperus rotundus aqueous extract concentrations.

\begin{tabular}{cccc}
\hline Extract concentration $(\%)$ & SFW $(\mathrm{g})$ & RFW $(\mathrm{g})$ & $\mathrm{RL}(\mathrm{cm})$ \\
\hline 0 & 116.44 & 14.14 & 17.40 \\
50 & 104.40 & 13.62 & 16.60 \\
100 & 116.40 & 22.52 & 22.20 \\
150 & 127.40 & 20.04 & 22.80 \\
200 & 131.20 & 25.76 & 26.40 \\
\hline F & $0.63 \mathrm{~ns}$ & $6.03^{* *}$ & $3.95^{\star *}$ \\
CV $(\%)$ & 24.99 & 23.70 & 21.49 \\
\hline
\end{tabular}

ns, ${ }^{* *}$ : not significant, and significant to $1 \%$ of probability $\mathrm{F}$ test, respectively.

There was a significant linear fit, significant to $1 \%$ of probability, to the averages as a function of extract doses, with 14.14 and $25.76 \mathrm{~g}$ root fresh weight for Cyperus rotundus extract concentrations of 0 and $200 \%$, respectively, showing that root weight increases with increasing extract concentrations (Figure 1A). Câmara et al. (2016) report that Cyperus rotundus extract positively influenced survival and sprouting percentages in acerola (Malpighia glabra L.) minicuttings.

Root length ranged from 16.40 to $26.40 \mathrm{~g}$ at Cyperus rotundus extract concentrations of 0 to $200 \%$, respectively, with root growth as a function of increasing extract concentrations (Figure 1B).
A.

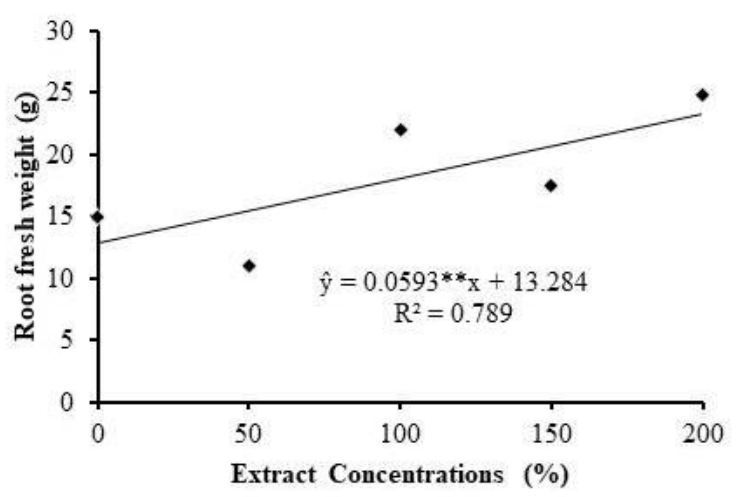

B.

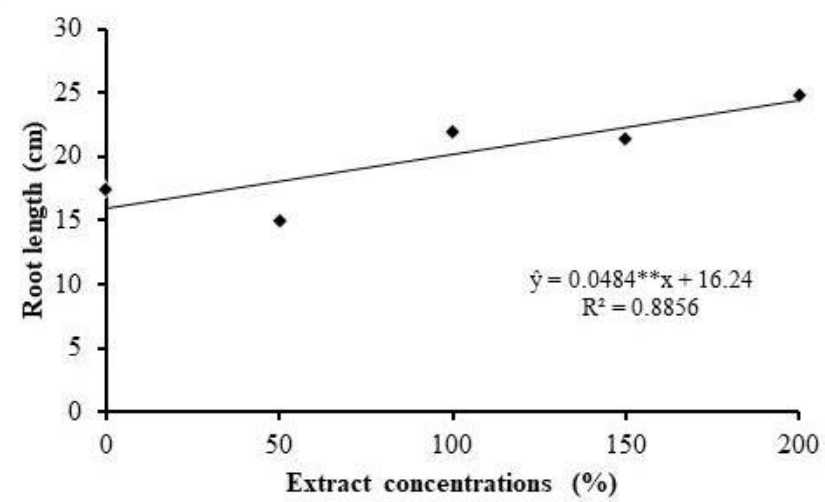

Figure 1 - Root fresh weight (A) and root length (B) of lettuce as function of Cyperus rotundus aqueous extract concentrations.

Souza et al. (2012) describe that Cyperus rotundus extract regulates some substances in plant metabolism, stimulating the rooting of some species in a similar manner to auxins. Lorenzi (2000) corroborates by stating that Cyperus rotundus has a high level of indolbutyric acid (IBA), that is a specific phytoregulator that induces root formation.

For tomato, concentrations of aqueous extract of Cyperus rotundus significantly affected shoot fresh weight (SFW), root fresh weight (RFW), and root length (RL) (Table 3). There was a significant linear adjustment in the averages as a function of the extract doses in the analyzed variables, being applied the regression test in RFW and $\mathrm{RL}$, where both presented responses according to the concentrations of the aqueous extract of Cyperus rotundus. Which explains the results found in the present study, taking into account the levels of indolbutyric acid that the extract presents, guaranteeing the reuse of materials produced by nature itself, aiming at the quality of life and plant growth (Cardoso et al., 2007).

Tomato shoot fresh weight ranged from 5.60 to $57.58 \mathrm{~g}$ at concentrations from 0 to $200 \%$, respectively. Cyperus rotundus extract concentrations of 50 to $150 \%$ led to a lower shoot fresh weight compared to the control treatment. This caused epinasty during crop development, in which leaves show curvatures. The highest dose did not cause such a pronounced effect, and led to the highest values of SFW, thus showing a positive response of extract application. Villa et al. (2016) report that Cyperus rotundus extract concentrations of $0,20 \%, 40 \%, 60 \%, 80 \%$, and $100 \%$ did not 
influence the germination of yellow passion fruit (Passiflora edulis F.) seeds. In contrast, high concentrations of Cyperus rotundus extract impaired the ger- mination potential of turnip, broccoli, cauliflower and radish (Andrade et al., 2009).

Table 3 - Variance analysis for shoot fresh weight (SFW), root fresh weight (RFW), lettuce root length (RL) of tomato as a function of Cyperus rotundus aqueous extract concentrations.

\begin{tabular}{cccc}
\hline Extract concentration $(\%)$ & SFW $(\mathrm{g})$ & RFW $(\mathrm{g})$ & $\mathrm{RL}(\mathrm{cm})$ \\
\hline 0 & 7.21 & 1.98 & 29.40 \\
50 & 6.69 & 1.73 & 32.40 \\
100 & 6.75 & 1.93 & 35.80 \\
150 & 5.60 & 2.21 & 39.60 \\
200 & 57.58 & 10.32 & 60.00 \\
\hline F & $85.35^{* *}$ & $15.74^{* *}$ & $4.68^{* *}$ \\
CV $(\%)$ & 32.94 & 37.95 & 31.72 \\
\hline
\end{tabular}

** Significant to $1 \%$ of probability by $\mathrm{F}$ test, respectively.

Tomato fresh weight (Figure $2 \mathrm{~A}$ ) and root length (Figure 2B) ranged from 1.98 to $10.32 \mathrm{~g}$ and 29.40 to $60.00 \mathrm{~cm}$, respectively, at Cyperus rotundus extract concentrations of 0 to $200 \%$. Thus, higher concentrations of the extract favored tomato root growth, consequently providing the ability to absorb and retain water, nitrogen, and other nutrients during initial growth. Silva et al. (2016) found a statistically signifi-

A.

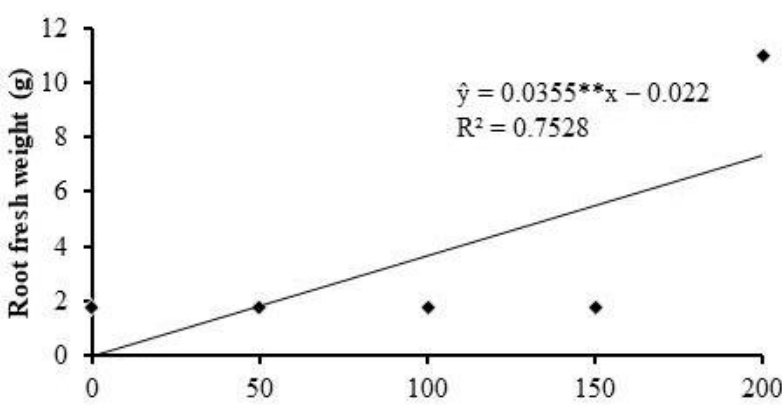

cant difference for Cyperus rotundus extract concentration of $50 \%$ compared to the concentrations of $25 \%$, $100 \%$, and the control treatment $(0 \%)$. The authors assumed that the $50 \%$ concentration of the extract increased auxin content in the cuttings, favoring blackberry root growth.

Figure 2 - Root fresh weight $(A)$ and root length (B) of lettuce as function of Cyperus rotundus aqueous extract concentrations.

\section{Conclusions}

1 - Higher concentrations of Cyperus rotundus leaf extract significantly affected the initial growth of lettuce plants;

2 - Studies on allelopathic effects between plants are extremely important because the use of this extract can contribute to seedling growth;

3 - The Cyperus rotundus extract concentration of $200 \%$ increased root and shoot growth in tomato crop; 4 - The application of increasing doses of Cyperus rotundus leaf extract on lettuce and tomato affected the growth and development parameters of these crops.

\section{References}

Andrade HM, Bittencourt AHC, Vestena S. (2009). Allelopathic potential of Cyperus rotundus L. upon cultivated species. Ciência e Agrotecnologia, Lavras 33(SPE):1984-1990.
B.

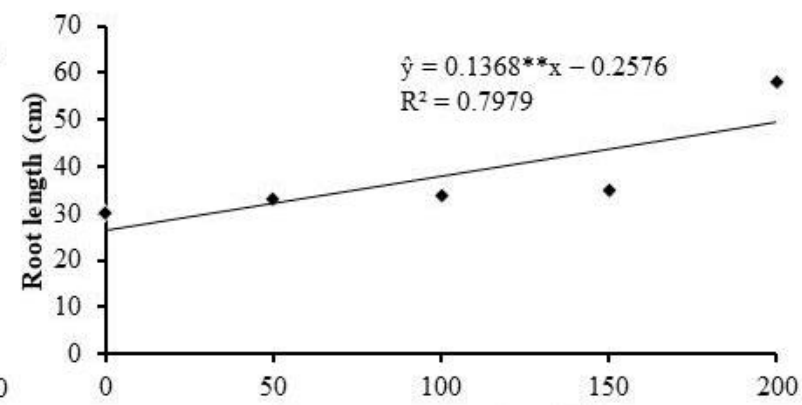

Barbosa JC, Maldonado Junior W. (2010). Agrostat Sistema para análises estatísticas de ensaios agronômicos. Jaboticabal: Departamento de Ciências Exatas. 10.

Câmara FMM, Carvalho S, Mendonça V, Paulino RC, Diógenes FEP. (2016). Sobrevivência, Enraizamento e biomassa de miniestacas de aceroleira utilizando extrato de tiririca. Comunicata Scientiae. 7(1): 133-138.

Cardoso MG, Muniz FR, Pinho EVRV, Vilela M. (2007). Qualidade Fisiológica de sementes de milho, feijão, soja e alface na presença de extrato de tiririca. Revista Brasileira de sementes. 29(2):195-204.

Carvalho JL, Pagliuca LG. (2007) Tomate: Um mercado que não para de crescer globalmente. Revista Hortifruti Brasil, Piracicaba-SP. 58(1): 6-14. 
Carvalho LB, Cruz-Hipolito H, González-Torralva F, Alves PLC, Christoffoleti PJ, Prado R. (2011). Detection of Sourgrass (Digitaria insularis) Biotypes Resistant to Glyphosate in Brazil. Weed Science, Washington. 59(2):171-176.

Costa E, Durante LGY, Nagel PL, Ferreira CR, Santos, A. (2011). Qualidade de mudas de berinjela submetida a diferentes métodos de produção. Revista Ciência Agronômica, Fortaleza-CE. 42 (4):1017-1025.

Domínguez J, Lazcano C, Gómez-Brandón M. (2010). Influencia del vermicompost en el crecimiento de las plantas. Aportes para la elaboración de um concepto objetivo. Acta Zoológica Mexicana, Cidade do México, 2:359-371.

Leão MFM, Duarte JA, Schimitt EG, Quintana LD, Zambrano LAB, Rocha MB, Zuravski L, Oliveira LFS, Machado MM. (2016). Avaliação da eficiência de extração dos polifenóis de amostras de chá através de métodos domésticos. Eletronic Journal of Pharmacy, Goiania. 13(2):82-88.

Li ZH. Wang Q. (2010). Phenolics and plant allelopathy. Molecules. 15:8933-52.

Lorenzi H. (2000) Plantas daninhas do Brasil: terrestres, aquáticas, parasitas e tóxicas. Nova Odessa, SP: Instituto Plantarum. 3.

Martins CR, Lopes WA, Andrade JB. (2013). Solubilidade das substâncias orgânicas. Química Nova, São Paulo. 36(8)1248-1255.

Monquero PA, Amaral LR, Inácio EM, Brunhara JP, Binha DP, Silva PV. Silva AC. (2009). Efeito de adubos verdes na supressão de espécies de plantas daninhas. Planta Daninha. Viçosa. 27(1):85-95.
Oliveira AKM, Pereira KCL, Muller JAI, Matias R. (2014). Análise fitoquímica e potencial alelopático das cascas de Pouteria ramiflora na germinação de alface. Horticultura Brasileira, Vitória da Conquista. 32(1):41-47.

Shah NA, lqbal J, Fahad S, Tanveer M, Yang G, Khan EA, Shahzad B, Yousaf $M$, Hassan W, Ullah A, Bukhari MA, Salah A, Saud S, Alharby H. (2017). Allelopathic influence of sesame and green gram intercrops on cotton in a replacement series. CLEAN-Soil, Air, Water. 45:e1500469.

Shah AN, lqbal J, Ullah A, Yang G, Yousaf M, Fahad S, Tanveer M, Hassan W, Tung SA, Wang L, Khan A, Wu Y. (2016). Allelopathic potential of oil seed crops in production of crops: a review. Environmental Science and Pollution Research. 23:14854-67.

Silva AB, Mello MRF, Sena AR, Lima Filho RM, Leite TCC. (2016). Efeito do extrato de Cyperus rotundus L. no enraizamento de estacas de amoreira-preta. Revista CIENTEC.9(1):1-9.

Silva AC, Silva VSG, Mantovanelli BC, Santos GM. (2017). Formação de mudas de alface em diferentes bandejas e substratos. Revista da Universidade Vale do Rio Verde, Três Corações.15(1):465-471.

Souza MF, Pereira EO, Martins MQ, Coelho RI, Pereira Junior OS. (2012). Efeito do extrato de Cyperus rotundus na rizogênese. Revistas de Ciências Agrárias, Lisboa. 35(1):157-162.

Villa F, França DLB, Rech AL, Moura CA, Fuchs F. (2016). Germinação de sementes de maracuja-amarelo em extrato aquoso de tiririca e ácido giberélico. Revista de Ciências Agroveterinárias. 15(1):3-7. 